\title{
Gençlerin Kişilik Özellikleri ile Yaşılılara Karşı Tutumları Arasında Yaşam Boyu Öğrenmenin Düzenleyici Rolünün İncelenmesi
}

Ece Naz ERMIŞS (*)

Öz: Bu çalışmanın amacı gençlerin kişilik özellikleri ile yaşlılara karșı tutumları arasındaki ilişkide yaşam boyu öğrenme düzeyinin düzenleyici rolünü incelemektir. Araştırma tesadüfi örneklem metodu ile seçilen yaşları 17 ile 29 yaşları arasında 278 üniversite öğrencisi ile yapılmıştır. Ayrıca gençlerin yaşlılara dair tutumlarının, yaşa, cinsiyete, bir yaşlı kimse ile bir süre aynı evi paylaşmış olup olmamalarına göre değișip değişmediği incelenmiştir. Çalışmada, Yaşlılara Karşı Tutum Ölçeği, 5 Faktör Kişilik Özellikleri Ölçeği kısa formu ve Yaşam Boyu Öğrenme Ölçeği kullanılmıştır. Yapılan t-testi analizleri sonucunda kadın ve erkekler arasında yaşlılığa ilişkin tutumlar açısından istatistiksel açıdan bir fark yoktur. Gençlerin bir dönem bir yaşlı ile birlikte yaşayıp yaşamama durumları yaşlılara iliş̧in tutumlarında anlamlı bir fark yaratmamaktadır. Pearson korelasyon analizi sonucunda gençlerin yaşları ile yaşlılara dair tutumları arasında anlamlı bir ilişki bulunmamıştır. Gençlerin uyumluluk ve dışadönüklük kişilik özellikleri ile yaşlılara dair tutumları arasında pozitif yönlü istatistiksel açıdan anlamlı bir ilişski bulunmuştur. Yaşam boyu ögrrenme düzeyinin bu ilişkileri düzenleyici rolü istatistiksel olarak anlamlıdır. Yapılan korelasyon analizi sonucunda gençlerin nevrotiklik özellikleri ile yaşlılara dair tutumları arasında negatif yönlü istatistiksel açıdan anlamlı bir ilişski bulunmuştur. Hiyerarşik regresyon analizi sonucuna da göre yaşam boyu öğrenme düzeyinin bu ilişkide düzenleyici rolü istatistiksel olarak anlamlı görüllmüşürr. Araştırmanın güçlü yönleri, sınırlıllkları ve katkıları ilgili alan yazın ışı̆̆ı̆ da tartışılmışıtır.

Anahtar Kelimeler: Yaşlılık, yaşam boyu öğrenme, kişilik özellikleri.

\section{Investigation of the Moderating Role of Lifespan Learning between Young People's Personality Traits and Attitudes Towards the Elderly}

\begin{abstract}
The current study investigated the moderating role of lifespan learning on the relationship between the personality traits of young people and their attitudes towards the elderly. The participants were 278 university students ranging from 17 to 29 years in age. Random sampling method was used in the study. This study also investigated whether young people's attitudes towards the elderly change according to gender and age, whether they share the same home with an elderly relatives. According to the results of the analysis, a statistically significant relation wasn't found between young people's age and scores of their attitude towards the elderly. Whether young people live an elderly for a while or not didn't make a significant difference in their attitudes towards the elderly. It was found a positive and statistically significant relationship between adaptability and extraversion personality traits of young people and their attitudes towards the elderly. There was a significant moderating effect of lifespan tendency on the relationship between adaptability and extraversion personality traits of young people and their
\end{abstract}

*) Doktor Öğretim Üyesi, İstanbul Kültür Üniversitesi Fen Edebiyat Fakültesi Psikoloji Bölümü Türk Dili ve Edebiyatı (e-posta: e.ermis@iku.edu.tr) (D ORCID ID. https://orcid.org/0000-00033054-2014

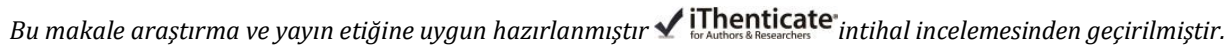


attitudes towards the elderly. It was found a negative statistically significant relationship between the neuroticism characteristics of the young people and their attitudes towards the elderly. There was a significant moderating effect of lifespan tendency on the relationship between neuroticism characteristics of the youth and their attitudes towards the elderly. The strengths, limitations, and contributions of this study are discussed in the light of the relevant literature.

Keywords: Aging, lifespan learning, personality characteristics.

Makale Gelis Tarihi: 27.06.2021

Makale Kabul Tarihi: 20.11.2021

DOI: $10.53487 /$ ataunisosbil.958276

\section{Giriş}

Yaşlılık, kişilerin psikolojik, fiziksel ve sosyolojik işlevlerinde değişikliklerin meydana geldiği ve bireylerin çevreye uyumunun bozulduğu bir dönemdir (HamadaniZadeh vd., 2008). Yaşlılıkta olan bu değişimlerle beraber kişilerin yaşlılığa dair tutumları, ön yargıları ve inançları şekillenmektedir (Erdemir, 2017). Bazı olumsuz kalıp fikirler yaşlılara karşı hizmet sunanların yaşlılık dönemindeki bireylerin yaşam kalitesinin yükselmesine ve sağaltımlarına engel oluşturabilmektedir. Sağlıklı, aktif yaşlanma ve yaşlıların toplumdaki diğer kişilerle bütünlük içinde yaşayabilmeleri ve ayrımcılığa maruz kalmamaları için yaşlılığa yönelik olumsuz inanç ve tutumların değişmesi önem taşımaktadır (Erdemir, 2017).

Türkiye'de 2060 yılına gelindiğinde yaşlıların genel nüfus içindeki yerinin istatistiki sonuçlara göre çocuk sayısından fazla olacağı ve gerekli düzenlemeler yapılmazsa yaşlı nüfusla yaşamak konusunda tüm toplum üyelerini zorlayıcı süreçlerin beklediği düşünülmektedir (Kurtkapan, 2020). Buradan yola çıkarak bu çalışmaya da katılımcı olarak eşlik eden 2000 li yılların başlarında doğmuş olan gençlerin yaşlılıklarının denk düşeceği bu önemli dönem için onların yaşlılığa ilişkin beklenti, istek ve tutumlarına bakmak gerekmektedir.

Genç bireylerin yaşlılı̆̆a dair tutumları, onlar hakkındaki düşüncelerine göre şekillenir. Gençler ve yaşlıların "yaşı ı yetişkin grubu" algılayışı arasında farklar vardır. Yapılan bir çalışmada genç yetişkinler, yaşlı ve genç bireyler arasında daha fazla fark sıralarken, yaşlı yetişkinler gençler ve yaşlılar arasında çok daha az fark olduğunu ifade etmişlerdir (Turner \& Oakes, 1989). Alan yazında gençlerin ve yetişkinlerin yaşlılıkla ilgili fikirlerine, herhangi bir yaşlı yakınlarına dair duydukları yükümlülük hissi, sevgi, yakınlık ve cinsiyet gibi faktörlerin etki ettiğine dair kanıtlar vardır fakat bunlar gençlerin yaşlılara dair tutumlarını açıklamak konusunda yeterli gelmeyebilir (Triandis \& Bhawuk, 1997). Artan eğitim seviyesi ve bilgiye rağmen, yaşlılara karşı olumsuz tutumlar hâlâ devam ediyorsa; yaş, etnik köken, meslek, sosyo-ekonomik durum ve başka birtakım demografik özellikler yaşlılara karşı tutumları tutarlı bir şekilde öngörmüyorsa (McTavish, 1971; Lutsky, 1980), kişilik özellikleri gibi temel bir değişkenin de tutumlar üzerinde farklılıklar yaratabileceği sorusu akla gelmektedir.

Kişilik özellikleri ile yaşlılara yönelik tutumlar arasındaki ilişkiyi ortaya koyan az 
sayıda çalışma bulunmaktadır. Kogan (1961) yaşlılara yönelik kendi kişilik ölçeğini geliştirmiş ve yaşlı insanlara karşı olumsuz tutumların otoriterlik özelliğiyle; olumlu tutumların ise fiziksel ve duygusal açıdan kapsama özelliğiyle ilişkili olduğunu bulmuştur. Thorson \& Perkins (1981), "Edwards Kişisel Tercih Programı" (1959) çalışmalarının sonucunda, kişilik özelliklerine ilişkin anlamlı bulgular elde etmişlerdir. Saldırganlık özelliğinde daha yüksek puan alan kişilerin yaşlı yetişkinlere karşı daha olumsuz tutumlar sergilediği sonucuna varılmıştır. Yapılan bir başka çalışma kişilik özelliklerinin yaşlanmaya ve yaşlı insanlara yönelik tutumlarla önemli ölçüde ilişkili olduğunu göstermektedir. Bu özelliklerin üç kişilik grubuna dahil edildiği gösterilmiştir (Cattell, Eber \& Tatsuoka, 1970). Bunlar; düşük anksiyete özellikleri, hassas sezgi özellikleri ve entelektüel yetenekler şeklindedir. Kendi gelecekleri hakkında daha karamsar veya endişeli hisseden, hayatlarında anlam bulamayan ve hayatın daha tehlikeli olduğu görüşlerine sahip olan bireyler, yaşlılığa değersiz, bağımlı, fiziksel olarak düşüşte olunan, çaresizlik ve kırılganlık duygularının çokça ortaya çıktığı bir dönem olarak bakarlar (Kogan, 1961). Tersine, yaşlı yetişkinler için olumlu görüşlere sahip insanlar daha az endişeli bireyler olma eğilimindedirler. Daha kuvvetli benlik gücüne, duygusal kararlılığa ve becerikliliğe sahiptirler. Sosyal olarak daha cesur ve maceracıdırlar, bu insanlar kendilerinin veya başkalarının savunmasızlıkları hakkında daha az endişe ya da korku duyarlar. Yaşamın engellerini ve krizlerini ele alma konusunda daha fazla kendilerine güveniyorlardır ve özellikle yaşlılığa uyum sağlama düşüncesi konusunda endişeli değillerdir (Katz, 1990). Geriatrik sağlık uzmanları ile yapılan bir çalışmada, empati, sağduyu ve duygusallık olarak (Cornwell, 2012) olumlu tutumlarla ilgili çeşitli kişilik özellikleri tanımlanmış ve kadınların bu nitelikleri barındırma ve dolayısıyla yaşlılara karşı olumlu tutum sergileme olasılığının daha yüksek olduğu bulunmuştur. Saygı ve nezaket gibi sosyal işlevsellikle ilgili kişilik özelliklerinin de yaşlılara dair olumlu tutumlarla örtüştüğü ortaya konmuştur (Sung, Kim \& Torres-Gil, 2010). Y kuşağına mensup gençlerin hayatlarında rahatlık kendinden önceki kuşağa oranla daha önemlidir. Çalışmayı sevdikleri gibi eğlenmeyi de daha çok seven bir kuşaktırlar. Bu özellikler onların yaşlılara dair tutumlarının da belirleyicisi olabilmektedir. Teknolojik gelişimlerin içinde büyüdükleri için diğer kuşağa kıyasla daha bireyci kişilik özellikleri gösterirler, dolayısıyla yaşlılara bakım konusunda daha az sorumluluk hissedilebilmekte ve daha az tahammüllü tutumlar da geliştirebilmektedirler (Kurtkapan, 2020). Böylelikle temel birtakım kişilik özelliklerinin, gençlerin hem kendi yaşlılıklarına hem de çevresindeki yaşlılara karşı tutumlarında majör bir etkiye sahip olduğu görülmektedir.

Yaşlanma konusundaki tutumlar, yetişkinler ve yaşlıların yeniden eğitim ve öğretime katılması açısından karar vermede önemli bir rol oynamaktadır. Moody (1976) yetişkinlerin ve yaşlıların eğitimine yönelik yaklaşımlarda dört gelişim aşaması sunmuştur. Aşama I, reddetme, toplumumuzda yaşlanmaya ilişkin olumsuz tutumların bir ürünüdür. $\mathrm{Bu}$ tutum daha çok, bilişsel yeteneğin yaşla birlikte azaldığına inanıldığından ortaya çıkmaktadır. Bu yüzden işverenler yaşlı yetişkin çalışanlarını eğitmek için uğraşmak istemezler (Sterns \& Harrington, 2019). Aşama II, sosyal hizmet kurumlarında yaşlılar için verilen eğitimi "boş zaman" etkinliği olarak değerlendirmesi şeklindedir. Yaşlı yetişkinler için ifade edilen eğitimin, büyük eğitim ve öğretim faaliyetlerinden açıkça ayrıldığı varsayılmaktadır. III. ve IV, evre kendini 
gerçekleştirmeye yaklaşan evreler olarak kabul edilir. Bu evreler yaşlı yetişkinlikteki kişisel gelişim dönemi olarak tanımlanır. Kişisel gelişim ve kişisel memnuniyet konuları üzerinde durulur. Birtakım işler ve sorumluluklardan ayrılma veya yeniden düzenleme gerekebilir, yaşı yetişkin böylelikle, daha önceki çalışma ve aile bakım sorumluluklarının gerektirdiği rollerden de kurtarılabilir. $\mathrm{Bu}$ aşamalar göz önüne alındığında yaşam boyu öğrenme kavramının önemli olduğu düşünülmektedir.

Yaşam boyu öğrenme kavramı, kişilerin yaşamlarını yönetebilmeleri adına ihtiyaç duydukları bilgileri edinebilme becerisi şeklinde tanımlanır (Günüç, Kuzu \& Odabaşı, 2012). Yaşam boyu öğrenme becerisi, bireylere örgün eğitim kariyerlerinin çok ötesinde beceri kazanma ve bilme firsatı vererek, onları adaptasyona ve büyümeye teşvik eder. Yaşam boyu öğrenme algısı, eğilimi ya da becerisinin gelişimi, kuşaklararası beraber bir çalışma ortamına entegre olma firsatını sağlar (Sterns \& Harrington, 2019). Araştırmalar, yaşlıların genç meslektaşları kadar öğrenme yeteneğine sahip olduklarını göstermiştir (Baltes \& Labouvie, 1973). Gençlikte daha uzun ve daha olumlu eğitim deneyimleri olanların yaşlılığa ulaştıklarında, örgün eğitime katılmaya daha istekli oldukları görülmektedir (March vd., 1977).

Gençler tarafından genellikle yaşlıların atıl olarak algılanmasından, yaşlılığın öğrenme konusunda gerilemiş bir dönem olduğunun düşünülmesi fikri de sorumludur (Arslan, 2016). Yaş alma ile beraber öğrenme konularında zayıflamalar olabilse de yaşlıların kristalize zekaları sayesinde elde ettikleri deneyimleri kullanma ve problem çözme becerileri fazlalaşmaktadır (Oktay, 2019). Bu sebeple yaşlılara, yeni bilgileri eski deneyimleri ile bütünleştirebilmeleri için şans tanınması gerekmektedir. Genç bireylerin çevrelerinde aktif, dinamik, gelişime ve öğrenmeye açık yaşlıların olması yaşlılığa dair bakış açılarının daha olumlu olmasını sağlayacaktır. (Arslan, 2016). Yaşlanma süreci, üretkenliğine devam eden, sevgisini paylaştıran, elindeki kaynaklarla yaşamdan doyum sağlayabilen bireyler için oldukça verimli bir dönem şeklinde de algılanabilir. Bu gelişim dönemi ikinci bahar, altın çağ olarak yorumlanıp, olumlu anlamda atıflarla anılabilir. Böylelikle yaşlı bireyler sahip oldukları potansiyellerini kullanma ve geliştirme firsatı bulabileceklerdir (Akdemir vd., 2007).

Yaşam boyu öğrenme becerisine sahip bireylerin birtakım ortak kişilik özelliklerinin olduğu düşünülmektedir. Literatürde yaşam boyu öğrenme düzeyi yüksek olan bireyin genel özelliklerinden biri "kendi öğrenme sürecini kontrol edebilmesi” (Epçaçan, 2013) olarak tanımlanmıştır. Buradan yola çıkarak kişi öğrenme deneyimlerinde kendi sorumluğunu alarak, uzun vadeli planlarını düzenleme becerisine de sahiptir (Mülhim, 2018). K1lıçer (2011) yaşam boyu öğrenme için ayrıca merakın da önemli bir harekete geçirici güç olduğunu söylemiştir. Yaşam boyu öğrenme ile aktif yaşlanma arasında güçlü bir ilişki olduğu düşünülmektedir. Aktif ve başarılı yaşlanabilmek için öncelikle tüm öğrenme etkinliklerine katılmaya istekli ve eğilimli olmak gerektiğine inanılır (Aydın \& Sayılan, 2014). Yaşam boyu öğrenme becerisinin ve algısının da daha genç yaşlardan itibaren eğitilmesi ve geliştirilmesi oldukça önemlidir.

Dünya Sağlık Örgütü (2014), yaşam boyu öğrenme fikirlerine uygun tasarlanmış modellerin, yaşlıların uyumlu ve özerk halde olabilmelerine, yaşamlarını sürdürebilecek 
becerilerini ve özgüvenlerini arttırmalarına katkıda bulunduğunu belirtmektedir. Kuşaklararası beraberce öğrenmenin yaşlılara bakış açısında olumlu pek çok etkisi bulunmaktadır. Yapılan çalışmalar, ileri yetişkinler ile bir arada öğrenen genç yetişkinlerin, ileri yetişkinlere karşı daha olumlu, içten ve yardımsever yaklaşımlar içerisinde olduğunu göstermektedir (DSÖ, 2014).

Öğrenme sürecinde kişilik özellikleri de işin içine katılır. Hem genetik geçişli özellikler hem de bağlamsal faktörlerin etkilerinin toplamı olan kişilik, Mischel ve arkadaşlarına (2008) göre kişinin tüm duyguları, düşünceleri, tutum ve davranışlarını içeren bütünlüklü ve kendi içinde gelişen bir dinamiktir. McCrae \& Costa, (1997) tarafından geliştirilen beş faktör kişilik kuramında kişilik; dışadönüklük, duygusal dengesizlik (nevrotiklik), yumuşak başlılık(uyumluluk), sorumluluk ve deneyime açıklık faktörlerinden oluşmaktadır. Dışadönük bireyler sosyal iletişim ve arkadaşlık ilişkilerine fazla zaman ayırırlar, özgüvenleri fazladır (Barrett \& Pietromonaco, 1997), yöneticilik vasıfları ile içinde oldukları grupları delege ederler (Barry \& Stewart, 1997). Sorumluluk özelliği olan kişiler düzenli, dikkatli ve disiplinlidir (Dollinger vd., 1996). Deneyime açıklık özelliği yüksek olanlar ise, meraklı, hayal gücü güçlü, iç görü düzeyi yüksek ilgi alanları geniş, gündelik yaşam problemlerine farklı bakış açıları ve esnek düşünceleri ile çözümler getirebilen kişiler olarak tarif edilirler (Sneed, McCrae \& Funder, 1998). Nevrotiklik kişilik özelliği dışında sayılan bu özelliklere sahip bireylerin yaşam boyu öğrenme eğilimlerinin yüksek olduğu düşünülmektedir. Çünkü yaşam boyu öğrenen bireylerin özellikleri incelendiğinde; yeni olana açık ve dikkatli olma, duygusal ve düşünsel olarak motive olabilme, sabırlı, meraklı ve öğrenme etkinliklerini düzenleme ve sürdürme gibi özelliklerin baskın olduğu görülmektedir (Diker Coşkun \& Demirel, 2012). Nevrotiklik kişilik özelliğinin ise yaşlılara karşı olumlu tutumlar arasında ters orantılı bir ilişkisinin olması beklenmektedir. Duygusal dengesizlik düzeyinin yüksek olmasının olumlu tutumlar üzerinde negatif etkisinin olabileceği beklenmektedir. Buradan yola çıkılarak bu çalışmada gençlerin hem kişilik özellikleri hem de yaşam boyu öğrenme isteklerinin yaşlılara karşı tutumlarına ne yönde etki ettiğinin incelenmesi amaçlanmıştır.

Araştırmada, yaşı ı yetişkinlerin bakım ihtiyaçlarının ortaya konulması, yaşlılarla uygun bir etkileşimin belirlenmesi ve toplumda yaşlı ayrımcılığının önüne geçebilmesi adına gençlerin yaşlılara dair düşüncelerinin tespit edilmesi amaç edinilmiştir. Gençlerin kişilik özellikleri ile yaşlılara dair tutumları arasındaki ilişkide, yaşam boyu öğrenme düzeylerinin bu ilişkiyi güçlendireceği yönünde bir varsayımdan yola çıkılmıştır. Gençlerin yaşam boyu öğrenme düzeylerinin yüksek olması, kavramın tanımı itibari ile kişilerin her yaş aralığında öğrenme ve üretme etkinliklerine açık olmaları anlamına gelir ve bu da gencin kendi yaşlılığını hayal ettiğinde gelecekte kendini nasıl gördüğüyle bağlantılı olarak yaşlılara karşı şu anki davranışlarını da şekillendirebilir. Ayrıca gençlerin kendi yaşlılıklarından bağımsız olarak da yaşam boyu öğrenme kavramını içselleştirmiş ya da bu beceriyi edinmiş olmalarının, yaşlı kimseleri de işe yarar, dinamik görmelerini sağlayabileceğini ve tutumlarına olumlu yansıyabileceğini düşündürmüştür.

Gençlerin yaşam boyu öğrenme düzeylerinin yüksek olması ya da bu beceriyi kazanmaları, sosyal sorumluluk ve gönüllülük etkinlikleri dahilinde kuşaklararası 
etkileşim ve dayanışmayı sağlayarak iki grup arasında bă̆ kurmaya yarayan bir etki oluşturabilir. Gençlerle yaşlılar ortak öğrenme etkinliklerinde (kurslar ve sosyal sorumluluk projeleri gibi) buluştuğunda, yaşlılar topluma aktif bir şekilde katılabilmekte ve kültürün yeni kuşaklara aktarılması rolünü üstlenmekte, bu da yaşlının kayda değer bir yerinin olduğunu düşünerek kendilerini ruhsal olarak daha iyi hissetmelerine neden olmaktadır. Gençler açısından da; empati, paylaşma, yardımlaşma ve dayanışma değerlerinin yaşlılar aracılığıyla deneyimlenmesi sağlanmaktadır (Canatan \& Boz, 2019). Bu durum da gençlerin yaşlılara olan tutumlarının olumlu şekilde değişmesini sağlayabilir. Tüm bu bilgilerin 1şığında gençlerin kişilik özellikleri ile yaşlılara dair tutumları arasında yaşam boyu öğrenme düzeylerinin düzenleyici rolü araştırılmıştır. Uyumlu, dışadönük, deneyime açık ve sorumluluk özellikleri yüksek gençlerin yaşlılara olan tutumlarının daha olumlu olacağı varsayılmış ve yaşam boyu öğrenme düzeylerinin de yüksek oluşunun bu ilişkiyi olumlu anlamda güçlendireceği temel hipotezinin test edilmesi amaçlanmıştır. Ayrıca gençlerin cinsiyet, yaş ve yaşıı bir yakını ile bir süre bir arada yaşama durumlarına göre de yaşlılara dair tutumlarının değişip değişmediği incelenmiştir. Buradan yola çıkarak oluşturulan hipotezler aşağıda belirtilmiştir:

Hipotez 1: Gençlerin cinsiyeti, yaşlılara dair tutumlarında bir fark yaratır.

Hipotez 2: Gençlerin yaşları ile yaşlılara dair tutumları arasında bir ilişki vardır.

Hipotez 3: Gençlerin yaşlı bir yakınları ile bir arada yaşayıp yaşamama durumları yaşlılara dair tutumlarında bir farklılık yaratır.

Hipotez 4a: Gençlerin uyumluluk kişilik özelliği ile yaşlılara karşı tutumları arasında bir ilişki vardır.

Hipotez 4b: Gençlerin dişadönüklük kişilik özelliği ile yaşlılara karşı tutumları arasında bir ilişki vardır.

Hipotez 4c: Gençlerin nevrotiklik kişilik özelliği ile yaşlılara karşı tutumları arasında bir ilişki vardır.

Hipotez 4d: Gençlerin deneyime açıklık kişilik özelliği ile yaşlılara karşı tutumları arasında bir ilişki vardır.

Hipotez 4e: Gençlerin sorumluluk kişilik özelliği ile yaşlılara karşı tutumları arasında bir ilişki vardır.

Hipotez 5: Gençlerin uyumluluk kişilik özelliği ile yaşlılara karşı tutumları arasındaki ilişkide yaşam boyu öğrenme düzeyleri düzenleyici role sahiptir.

Hipotez 6: Gençlerin dişadönüklük kişilik özelliği ile yaşlılara karşı tutumları arasındaki ilişkide yaşam boyu öğrenme düzeyleri düzenleyici role sahiptir.

Hipotez 7: Gençlerin nevrotiklik kişilik özelliği ile yaşlılara karşı tutumları arasındaki ilişkide yaşam boyu öğrenme düzeyleri düzenleyici role sahiptir.

Hipotez 8: Gençlerin deneyime açıklık kişilik özelliği ile yaşlılara karşı tutumları arasındaki ilişkide yaşam boyu öğrenme düzeyleri düzenleyici role sahiptir. 
Gençlerin Kişilik Özellikleri ile Yaşlılara Karşı Tutumları Arasında Yaşam Boyu Öğrenmenin Düzenleyici Rolünün İncelenmesi

Hipotez 9: Gençlerin sorumluluk kişilik özelliği ile yaşlılara karşı tutumları arasındaki ilişkide yaşam boyu öğrenme düzeyleri düzenleyici role sahiptir.

\section{Yöntem}

$\mathrm{Bu}$ bölümde; çalışmaya katılanlar, araştırma süreci, kullanılan analiz yöntemleri, araçları ve analiz sonucunda elde edilen bulgulara yer verilmiştir.

\section{A. Katılımcılar}

Araştırma 2020 senesinde üniversite öğrencileri ile gönüllülük ilkesine göre gerçekleştirilmiştir. Araştırmanın örneklem grubuna tesadüfi örnekleme yöntemi ile İstanbul'da bir vakıf üniversitesinin farklı bölümlerinde okuyan toplam 278 öğrenci dahil edilmiştir. Tanımlayıcı istatistiklere göre katılımcıların 166'sı kadın, 86'sı ise erkektir ( $\overline{\mathrm{x}}$ $=1,34$ ss= 0,47). Öğrencilerin yaşları 17 ile 29 arasındadır $(\overline{\mathrm{x}}=21,14$ ss= 3,16). Öğrencilerden 60 yaş ve üzeri bir akraba ya da yakınları ile yaşamlarının bir döneminde yaşamış olanlar 152, yaşamamış olanlar 100 kişi olarak değişmektedir $(\overline{\mathrm{x}}=2,46 \mathrm{ss}=$ 0,89 ).

\section{B. Veri Toplama Araçları}

Kişisel Bilgi Formu: Katılımcılardan; cinsiyet, yaş ve 60 yaş üzeri bir yakını veya akrabası ile yaşamış olup olmamasına ilişkin bilgiler alınmıştır.

Beş Faktör Kişilik Özelliği Ölçeği Kısa Formu: İnsanların kişiliklerini beş temel özellik üzerinden ölçmek için John, Donahue ve Kentle (1991) tarafından oluşturulmuştur. 44 maddelik ve 5'li likert tipi şeklindedir. Ölçek kişilik özelliklerinden "nevrotiklik”(dugusal dengesizlik), "dişadönüklük”, "gelişime-deneyime açıklık", "uyumluluk" ve "sorumluluk" boyutlarını ölçmektedir. (John ve Srivastava, 1999). Ölçeğin Türkçe'ye uyarlanması ise Sümer ve Sümer (2005) tarafindan yapılmıştır. Cronbach Alpha güvenilirlik değerleri .66 ile .77 aralığında değiştiği bulgulanmıştır. Schmitt ve arkadaşları (2007) çalışmasında beş faktör kişilik ölçeğinin Cronbach Alpha güvenirlik değerlerini .79, .77, .76, .70 ve .78 olarak sirasıyla "nevrotiklik", "dışadönüklük", "gelişime açıklık", "uyumluluk" ve "sorumluluk” olarak bulmuştur. 278 kişinin dahil olduğu bu çalışmada da ölçeğin tamamına ait iç tutarlılık katsayısı .72 olarak hesaplanmıştır. Alt faktörlerinden uyumluluk boyutu için .62, sorumluluk alt boyutu için .77, dışadönüklük boyutu için .83, nevrotiklik boyutu için .69 , ve deneyime açıklık alt boyutu için ise .62 olarak hesaplanmıştır.

Yaşam Boyu Öğrenme Ölçeği: Yelkin Diker Çoşkun tarafindan (2009) doktora tez çalışmasında üretilmiştir. 27 maddeden oluşan ölçeğin iç tutarlılık katsayısı .89 bulunmuştur. 6'lı likert tipi 4 alt boyutlu bir ölçektir. İlk iki boyut yaşam boyu öğrenmeye dair şefk ve çabayı ifade eden pozitif maddelerden son iki boyut ise yaşam boyu ögrenmeyi planlayamama ve bunun sebeplerine dair merak etmeme durumlarını belirten ifadelere sahip negatif maddelerden oluşan boyutlardır. 278 kişinin dahil olduğu bu çalışma için ölçeğin toplam puanı kullanılmıştır, alınan puanların yüksek oluşu, yaşam boyu öğrenme düzeyinin yüksek olduğunu ifade eder ve hesaplanan iç tutarlılık katsayısı .93 şeklindedir. 
Yaşılıara Karşı Tutum Ölçeği: Kogan (1961) ölçeği, yaşlılara dair tutumların tespit edilmesi sebebiyle geliş̧irmiştir. Adıbelli (2011) tarafindan Türkçe'ye uyarlanmıştır. 17 olumlu ve 17 olumsuz madde içermektedir. Olumsuz maddeler tersten puanlanarak genel puanlamaya eklenmektedir. 6'l likert tipi bir ölçektir ve alınacak puanlar 34 ile 238 arasında seyretmektedir. Ölçekten alınan puanların yüksek olması olumlu tutumların fazla olduğuna işaret eder. Cronbach Alfa güvenilirlik değeri ölçeğin bütünü için 0.84 olarak belirlenmiştir. Ölçeğin iki boyutu bulunur, olumlu tutumlar ve olumsuz tutumlar olmak üzere. Bu iki alt boyutun güvenilirlik değerleri de sırasıyla .78 ve .79 'dur. (Duyan ve Gelbal, 2013). 278 kişinin dahil olduğu bu çalışmada ölçeğin toplam puanı kullanılmıştır ve iç tutarlılık düzeyi .89 şeklindedir.

\section{C. İşlem}

Ölçek formu, sırasıyla bilgilendirilmiş onam ve demografik bilgi formu, Beş Faktör Kişilik Ölçeği Kısa Formu, Yaşam Boyu Öğrenme Ölçeği ve Yaşlılara Karşı Tutum Ölçeğinden oluşmaktadır. İlgili ölçeklerin kullanım izni yazarlardan alınmıştır. Çalışma İstanbul Kültür Üniversitesi'nde bulunan katılımcılarla gerçekleştirilmiş ve Google form üzerinden de katılımcılarla paylaşılmıştır. Katılımcılardan herhangi bir kimlik bilgisi istenmemiştir. Verilerin analizinde, IBM SPSS Statistics 23 programı kullanılmıştır.

\section{Bulgular}

\section{A. Demografik Değişkenlere Göre Gençlerin Yaşlılığa İliş̧kin Tutumlarının İncelenmesine İlişkin Bulgular}

Gençlerin cinsiyetleri ve yaşlı bir yakın ile bir arada yaşayıp yaşamama durumlarına dair hipotezler t-testi analizleri ile incelenmiş ve kadın ile erkekler arasında yaşlılığa ilişkin tutumlar açısından istatistiksel bir fark olmadığı görülmüştür $(t=888 ; p>.05)$. Gençlerin yaşamlarının bir dönemini yaşlı bir yakınları ile yaşayıp yaşamama durumlarının yaşlılara ilişkin tutumlarında istatistiksel açıdan bir fark yaratmadığı görülmüştür $(t=207 p>.05)$. Öğrencilerin yaşları ile yaşlılara dair tutumları arasında Pearson korelasyon analizi neticesinde anlamlı bir ilişki bulunmamıştır $(r=.57 ; p>.05)$.

\section{B. Korelasyon Analizine İlişskin Bulgular}

Tablo 1'e göre gençlerin uyumluluk düzeyleri ile yaşlılara ilişkin tutumları arasında istatistiksel açıdan zayıf, doğru orantılı ve istatistiksel olarak anlamlı bir ilişki bulunmuştur $(r=197, p<, 01)$. Buna göre gençlerin uyumluluk düzeyleri arttıkça yaşlılara ilişkin tutumları da olumlu yönde artmaktadır. Gençlerin sorumluluk düzeyleri ile yaşlılara ilişkin tutumları arasında istatistiksel açıdan zayıf düzeyde, doğru orantılı ve istatistiksel olarak anlamlı bir ilişki bulunmuştur $(r=, 193, p<, 01)$. Buna göre gençlerin sorumluk düzeyleri arttıkça yaşlılara ilişkin tutumları da olumlu yönde artmaktadır. Gençlerin dışadönüklük düzeyleri ile yaşlılara ilişkin tutumları arasında istatistiksel açıdan zayıf düzeyde, doğru orantılı ve istatistiksel olarak anlamlı bir iliş̧i bulunmuştur $(r=, 206, p<, 01)$. Buna göre gençlerin dışadönüklük düzeyleri arttıkça yaşlılara ilişkin tutumları da olumlu yönde artmaktadır. Gençlerin deneyime açıklık düzeyleri ile yaşılılara ilişkin tutumları arasında istatistiksel açıdan zayıf düzeyde, doğru orantılı ve 
Gençlerin Kişilik Özellikleri ile Yaşlılara Karşı Tutumları Arasında Yaşam Boyu Öğrenmenin Düzenleyici Rolünün İncelenmesi

istatistiksel olarak anlamlı bir ilişki bulunmuştur $(r=, 167, p<, 01)$. Buna göre gençlerin sorumluk düzeyleri arttıkça yaşlılara ilişkin tutumları da olumlu yönde artmaktadır. Gençlerin nevrotiklik düzeyleri ile yaşlılara ilişkin tutumları arasında zayıf düzeyde ters orantılı ve istatistiksel olarak anlamlı bir ilişki bulunmuştur $(r=-, 235, p<, 01)$. Buna göre gençlerin nevrotiklik düzeyleri arttıkça yaşlılara ilişkin tutumları da olumsuz yönde artmaktadır. Analizlerin 1şığında H4a, H4b, H4c, H4d ve H4e doğrulanmıştır. Gençlerin yaşam boyu öğrenme eğilimleri ile yaşlılara ilişkin tutumları arasında zayıf düzeyde ters orantılı istatistiksel olarak anlamlı bir ilişki bulunmuştur $(r=-, 260, p<, 01)$. Buna göre gençlerin yaşam boyu öğrenme düzeyleri arttıkça yaşlılara ilişkin tutumları da olumsuz yönde artmaktadır.

Tablo 1: Değişkenler Arası Korelasyon Katsayıları

\begin{tabular}{|c|c|c|c|c|c|c|c|}
\hline & 1 & 2 & 3 & 4 & 5 & 6 & 7 \\
\hline $\begin{array}{l}\text { 1.Yaşlılara } \\
\text { yönelik tutum }\end{array}$ & - &, $197 * *$ &,$- 260 * *$ &, $193 * *$ &, $206 * *$ &, $167 * *$ & , $235 *$ \\
\hline 2.Uyumluluk & & - &,$- 175^{* *}$ &, $196 * *$ &, $273 * *$ &, $273 * *$ &,$- 122 *$ \\
\hline $\begin{array}{l}\text { 3.Yaşam boyu } \\
\text { öğrenme }\end{array}$ & & & - &,$- 371 * *$ &,$- 257 * *$ &,$- 447 * *$ &, $196 * *$ \\
\hline 4.Sorumluluk & & & & - &, $124 *$ &, $186 * *$ & , $256 *$ \\
\hline 5.Dışadönüklük & & & & & - &, $455 * *$ & , $272 * *$ \\
\hline $\begin{array}{l}\text { 6.Deneyime } \\
\text { açıklık }\end{array}$ & & & & & & - & $-172 * *$ \\
\hline 7.Nevrotiklik & & & & & & & - \\
\hline
\end{tabular}

$* * \mathrm{p}<.01$

\section{Düzenleyici Değişken (Moderatör) Analizine İlişkin Bulgular}

Gençlerin beş faktör kişilik özelliklerinden biri olan uyumluluk, nevrotiklik, dışadönüklük, uyumluluk, sorumluluk ve deneyime açıklık özellikleri ile yaşlılara ilişkin tutumları arasındaki ilişkide yaşam boyu öğrenme eğilimlerinin düzenleyici rolünün incelenmesi amacıyla alt faktörlerin her biri ile ayrı ayrı düzenleyici değişken analizi uygulanmıştır. Uyumluluk, dışadönüklük, nevrotiklik değişkenlerinin düzenleyici 
rollerini gösteren analiz sonuçları tablo 2, tablo 3 ve tablo 4'te yer almaktadır.

Tablo 2: Gençlerin Uyumluluk Düzeyi ve Yaşlılara İlişkin Tutumlar Arasındaki İlişkide Yaşam Boyu Öğrenme Becerisinin Düzenleyici Etkisi

\begin{tabular}{|c|c|c|c|c|c|c|c|c|}
\hline Model & $\mathbf{R}$ & $\mathbf{R}^{2}$ & $\Delta \mathbf{R}^{2}$ & $\Delta \mathbf{F}$ & $\mathbf{F}$ & Değişkenler & $\boldsymbol{\beta}$ & $\mathbf{T}$ \\
\hline 1 & ,207 & ,043 & 039 & 10,561 & 10,561 & Uyumluluk & ,207 & $3,250 * * *$ \\
\hline \multirow[t]{3}{*}{2} & ,307 & ,094 & 087 & 13,385 & 12,250 & Uyumluluk &, 173 & $2,749 * *$ \\
\hline & & & & & & $\begin{array}{l}\text { Yaşam Boyu } \\
\text { Öğrenme }\end{array}$ & $\begin{array}{l}- \\
, 230\end{array}$ & - \\
\hline & & & & & & Uyumluluk & , 149 & $2,359 * *$ \\
\hline \multirow[t]{2}{*}{3} &, 333 &, 111 & ,099 & 4,249 & 9,696 & $\begin{array}{l}\text { Yaşam Boyu } \\
\text { Öğrenme }\end{array}$ & -239 & - $3,827 * * *$ \\
\hline & & & & & & $\begin{array}{l}\text { Uyumluluk*Yaşam } \\
\text { Boyu Öğrenme }\end{array}$ & - & $-2,061^{*}$ \\
\hline
\end{tabular}

$* * * \mathrm{p}<.001 ; * * \mathrm{p}<.01 ; * \mathrm{p}<.05$

Tablo 2' de uyumluluk ile yaşam boyu öğrenme etkileşiminin yaşlılara yönelik tutumlar üzerindeki katkıları sunulmuştur. Tabloda tüm modellerin anlamlı $(p<.05)$ olduğu görülmektedir. 2.modelde uyumluluk özelliğinin $(\beta=, 173, p<.01)$ ve yaşam boyu öğrenme becerisinin $(\beta=-, 230, p<.001)$ tek başlarına yaşl1lara yönelik tutumlar üzerinde anlamlı katkıları bulunmaktadır. Uyumluluğun, yaşlılara yönelik tutumlar üzerindeki etkisi $(\beta=, 173, p<.01)$, yaşam boyu öğrenme becerisinin etkisinden $(\beta=-, 230, p<.001)$ daha zayıftır. 3. Model incelendiğinde ise uyumluluk ile yaşam boyu öğrenmenin etkileşiminin yaşlılara yönelik tutumlar üzerinde de anlamlı bir katkısının $(\beta=-, 120$, $p<.05)$ olduğu görülmektedir. 3. modelde $\Delta \mathrm{F}$ de $(4,249, p<.05)$ anlamlıdır. Bu bulgular doğrultusunda, gençlerin yaşam boyu öğrenme becerisi, uyumluluk ile yaşlılara yönelik tutumları arasındaki ilişkide düzenleyici rolü üstlenmektedir. Bu bulgular 1şığında H5 (Gençlerin uyumluluk kişilik özelliği ile yaşlllara karşı tutumları arasındaki iliş̧kide yaşam boyu ögrenme düzeyleri düzenleyici role sahiptir) doğrulanmıştır. 

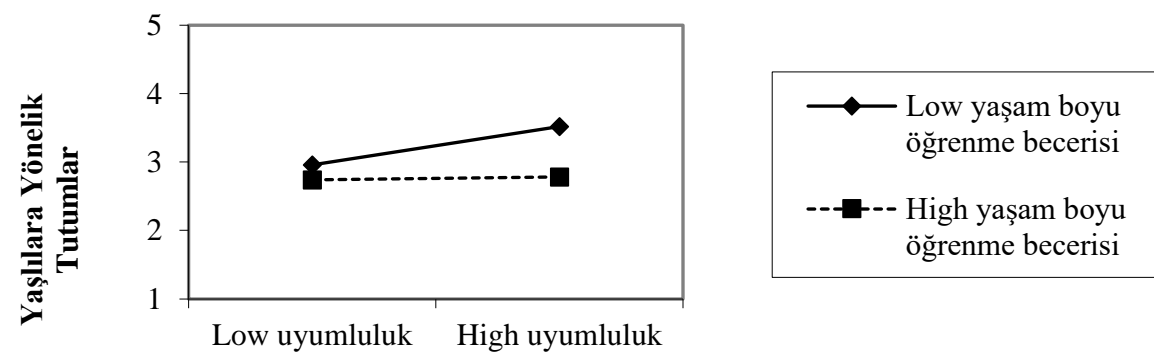

\section{Şekil 1: Etkileşim Grafiği}

Yaşam boyu öğrenme becerisinin, uyumluluk ve yaşlılara yönelik tutumlar arasındaki ilişkide üstlendiği düzenleyici rol Şekil 1'de görülmektedir. Buna göre, gençlerin uyumluluk düzeylerinin yaşlılara karşı olumlu tutumları üzerindeki etkisi, yaşam boyu öğrenme düzeylerinin düşük ve orta düzeyli olduğu zamanlarda artmaktadır. Yaşam boyu öğrenme düzeyleri yüksek olduğu durumlarda ise uyumluluk kişilik özelliğinin yaşlılara karşı olumlu tutumlar üzerindeki etkisi anlamsızlaşmaktadır. Yaşam boyu ögrenme ancak düşük ve orta düzeyli iken bu ilişkide düzenleyici bir katkısı olmaktadır.

Tablo 3: Gençlerin Dışadönüklük Düzeyi ve Yaşlılara İlişkin Tutumlar Arasındaki İlişkide Yaşam Boyu Öğrenme Becerisinin Düzenleyici Etkisi

\begin{tabular}{|c|c|c|c|c|c|c|c|c|}
\hline Model & $\mathbf{R}$ & $\mathbf{R}^{2}$ & $\Delta \mathbf{R}^{2}$ & $\Delta \mathbf{F}$ & $\mathbf{F}$ & Değişkenler & $\boldsymbol{\beta}$ & $\mathbf{T}$ \\
\hline 1 & ,205 &, 042 & ,038 & 10,178 & 10,178 & D1şadönüklük & ,205 & $3,190 * *$ \\
\hline 2 & ,293 & ,086 &, 078 & 11,220 & 10,922 & $\begin{array}{l}\text { Dişadönüklük } \\
\text { Yaşam Boyu } \\
\text { Öğrenme }\end{array}$ & $\begin{array}{l}, 147 \\
-, 218\end{array}$ & $\begin{array}{l}2,60 * \\
-3,350 * * *\end{array}$ \\
\hline \multirow[t]{2}{*}{3} &, 364 &, 133 &, 121 & 12,426 & 11,782 & $\begin{array}{l}\text { Dişadönüklük } \\
\text { Yaşam Boyu } \\
\text { Öğrenme }\end{array}$ & $\begin{array}{l}, 160 \\
-, 256\end{array}$ & $\begin{array}{l}2,509 * * \\
-3,974 * * *\end{array}$ \\
\hline & & & & & & $\begin{array}{l}\text { Dişadönüklük } \\
\text { *Yaşam Boyu } \\
\text { Öğrenme }\end{array}$ &,- 220 & $-3,525 * * *$ \\
\hline
\end{tabular}

$* * * \mathrm{p}<.001 ; * * \mathrm{p}<.01 ; * \mathrm{p}<.05$

Tablo 3' de dişadönüklük düzeyi ile yaşam boyu öğrenme etkileşiminin yaşlılara yönelik tutumlar üzerindeki etkileri gösterilmiştir. Tabloda tüm modellerin anlamlı 
( $p<.05)$ olduğu görülmektedir. 2.modelde dişadönüklüğün $(\beta=, 147, p<.05)$ ve yaşam boyu öğrenmenin $(\beta=-, 218, p<.001)$ tek başlarına yaşlılara yönelik tutumlar üzerinde anlamlı katkıları bulunmaktadır. Yaşam boyu öğrenmenin, yaşlılara yönelik tutumlar üzerindeki etkisi $(\beta=-, 218, p<.001)$, dişadönüklüğün etkisinden $(\beta=, 147, p<.05)$ daha güçlüdür. 3. Model incelendiğinde ise bu iki değişkenin etkileşiminin yaşlılara yönelik tutumlar üzerinde de anlamlı bir katkısının $(\beta=-220, p<.001)$ olduğu fark edilmektedir. 3. modelde $\Delta \mathrm{F}(12,426, p<.001)$ de anlamlı bulunmuştur. Bu sonuçlara göre, gençlerin yaşam boyu öğrenme becerisi, dışadönüklük ile yaşlılara yönelik tutumları arasındaki ilişkide düzenleyici rolü üstlenmektedir. Bu sonuçtan yola çıkarak H6 (Gençlerin dışadönüklük kişilik özelliği ile yaşlılara karşı tutumları arasındaki ilişkide yaşam boyu ögrenme düzeyleri düzenleyici role sahiptir) doğrulanmıştır.
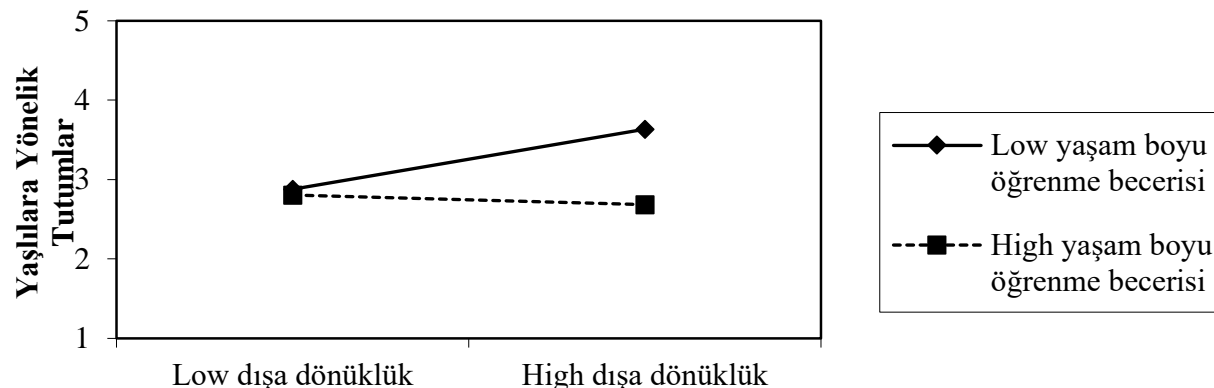

\section{Şekil 2: Etkileşim Grafiği}

Yaşam boyu öğrenme becerisinin, dişadönüklük ve yaşlilara yönelik tutumlar arasındaki ilişkide üstlendiği düzenleyici rol Şekil 2'de görülmektedir. Buna göre, gençlerin dışadönüklük düzeylerinin yaşlılara karşı olumlu tutumları üzerindeki etkisi, yaşam boyu öğrenme düzeylerinin düşük ve orta düzeyli olduğu zamanlarda artmaktadır. Yaşam boyu öğrenme düzeyleri yüksek olduğu durumlarda ise dişadönüklük kişilik özelliğinin yaşlılara karşı olumlu tutumlar üzerindeki etkisi anlamsızlaşmaktadır. Yaşam boyu öğrenme ancak düşük ve orta düzeyli iken bu ilişkide düzenleyici bir katkısı olmaktadır.

Tablo 4: Gençlerin Nevrotiklik Düzeyleri ve Yaşlılara İlişkin Tutumlar Arasındaki İlişkide Yaşam Boyu Öğrenme Becerisinin Düzenleyici Etkisi

\begin{tabular}{ccccccccc}
\hline Model & $\mathbf{R}$ & $\mathbf{R}^{2}$ & $\boldsymbol{\Delta} \mathbf{R}^{2}$ & $\boldsymbol{\Delta} \mathbf{F}$ & $\mathbf{F}$ & Değişkenler & $\mathbf{B}$ & $\mathbf{T}$ \\
\hline 1 &, 267 &, 071 &, 067 & 17,909 & 17,909 & Nevrotiklik &,- 267 & $-4,232^{* * *}$ \\
\hline 2 &, 337 &, 113 &, 106 & 14,837 & 14,837 & Nevrotiklik &,- 227 & $-3,600^{* * *}$ \\
& & & & & $\begin{array}{l}\text { Yaşam Boyu } \\
\text { Ögrenme }\end{array}$ &,- 209 & $-3,316^{* * *}$ \\
\end{tabular}


Gençlerin Kişilik Özellikleri ile Yaşlılara Karşı Tutumları Arasında Yaşam Boyu Öğrenmenin Düzenleyici Rolünün İncelenmesi

\begin{tabular}{|c|c|c|c|c|c|c|c|c|}
\hline & & & & & & Nevrotiklik &,- 215 & $-3,461 * * *$ \\
\hline \multirow[t]{2}{*}{3} & ,381 & , 145 & , 134 & 8,580 & 13,074 & $\begin{array}{l}\text { Yaşam Boyu } \\
\text { Ögrenme }\end{array}$ &,- 207 & $-3,335 * * *$ \\
\hline & & & & & & $\begin{array}{l}\text { Nevrotiklik } \\
\text { *Yaşam } \\
\text { Boyu } \\
\text { Öğrenme }\end{array}$ & , 179 & $2,929 * * *$ \\
\hline
\end{tabular}

$* * * \mathrm{p}<.001 ; * * \mathrm{p}<.01 ; * \mathrm{p}<.05$

Tablo 4' de nevrotiklik düzeyi ile yaşam boyu öğrenme etkileşiminin yaşlılara yönelik tutumlar üzerindeki katkıları gösterilmiştir. Tabloda tüm modellerin anlamlı $(\mathrm{p}<.05)$ olduğu fark edilir. 2.modelde nevrotiklik özelliğinin $(\beta=-, 227, \mathrm{p}<.001)$ ve yaşam boyu öğrenmenin $(\beta=-, 209, \mathrm{p}<.001)$ tek başlarına yaşlılara yönelik tutumlar üzerinde anlamlı katkıları bulunmaktadır. Nevrotikliğin, yaşlılara yönelik tutumlar üzerindeki etkisi $(\beta=-227, p<.001)$, yaşam boyu öğrenmenin etkisinden $(\beta=-, 209, p<.001)$ daha güçlüdür. 3. Model incelendiğinde ise bu iki değişkenin etkileşiminin yaşlilara yönelik tutumlar üzerinde de anlamlı bir katkısının $(\beta=, 179, \mathrm{p}<.001)$ bulunduğu anlaşılmaktadır. 3. modelde $\Delta \mathrm{F}^{\prime}$ 'in de $(8,580, \mathrm{p}<.01)$ anlamlı olduğu görülmektedir. Bu sonuçlara göre, gençlerin yaşam boyu öğrenme düzeyi, nevrotiklik ile yaşlılara yönelik tutumları arasındaki ilişkide düzenleyici etkiye sahiptir. Bu sonuçtan yola çıkarak H7 (Gençlerin nevrotiklik kişilik özelliği ile yaşlılara karşs tutumları arasındaki ilişkide yaşam boyu ögrenme düzeyleri düzenleyici role sahiptir) doğrulanmıştır.
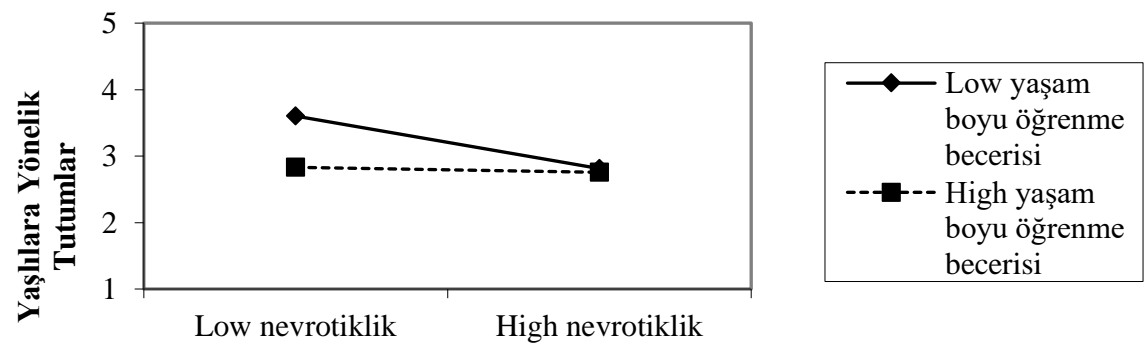

\section{Şekil 3: Etkileşim Grafiği}

Yaşam boyu öğrenme becerisinin, nevrotiklik ve yaşlilara yönelik tutumlar arasındaki ilişkide üstlendiği düzenleyici rol Şekil 3 teki etkileşim grafiğinde sunulmuştur. Buna göre, gençlerin nevrotiklik düzeylerinin yaşlilara karşı olumlu tutumları üzerindeki ters orantılı etkisi, yaşam boyu öğrenme düzeylerinin düşük ve orta düzeyli olduğu zamanlarda artmaktadır. Yaşam boyu öğrenme düzeyleri yüksek olduğu durumlarda ise nevrotiklik kişilik özelliğinin yaşlılara karşı olumlu tutumlar 
üzerindeki etkisi anlamsızlaşmaktadır. Yaşam boyu öğrenme ancak düşük ve orta düzeyli iken bu ilişkide düzenleyici bir katkısı olmaktadır.

Kişilik özelliklerinden deneyime açıklık ve sorumluluk alt faktörlerininin yaşlılara ilişkin tutumlar arasındaki ilişkide yaşam boyu öğrenme eğilimlerinin düzenleyici rolünün olup olmadığ incelenmiştir. Yaşlılara ilişkin tutumlar üzerinde deneyime açıklığın 2. modelde $(\beta=0,70, p>.05)$ tek başına anlamlı bir katkısı yoktur. 3. Model incelendiğinde ise deneyime açıklık ve yaşam boyu öğrenme değişkenlerinin etkileşimlerinin yaşlılara yönelik tutum üzerinde de anlamlı bir katkısının $(\beta=-, 117$, $p>.05)$ bulunmadığı görülmektedir. 3. modelde $\Delta \mathrm{F}(3,342, p>.05)$ anlamlı değildir. $\mathrm{Bu}$ bulgular doğrultusunda yaşam boyu öğrenme düzeyi, deneyime açıklık ile yaşlılara karşı tuutmlar arasındaki ilişkide düzenleyici değişken rolü üstlenmemektedir. Bu bulgular 1şı̆̆ında H8 (Gençlerin deneyime açıklık kişilik özelliği ile yaşlılara karşı tutumları arasındaki ilişkide yaşam boyu ögrenme düzeyleri düzenleyici role sahiptir) doğrulanmamıştır. Yaşlılara ilişkin tutumlar üzerinde sorumluluk kişilik alt boyutunun $(\beta=, 140, p<.05)$ ve yaşam boyu öğrenme becerisinin $(\beta=-, 203, p<.01)$ tek başlarına anlamlı katkıları bulunmaktadır. 3. Model incelendiğinde ise sorumluluk ve yaşam boyu öğrenme değişkenlerinin etkileşimlerinin yaşlilara yönelik tutum üzerinde de anlamlı bir katkısının $(\beta=-.051, p>.01)$ olmadığı görülmektedir. 3. modelde $\Delta \mathrm{F}$ $(0,082, p>.05)$ anlamlı değildir. Bu bulgular doğrultusunda yaşam boyu öğrenme becerisi, sorumluluk ile yaşlılara karşı tuutmlar arasındaki ilişkide düzenleyici değişken rolü üstlenmemektedir. Bu bulgular ışı̆̆ında H9 (Gençlerin sorumluluk kişilik özelliği ile yaşlılara karşı tutumları arasındaki ilişkide yaşam boyu öğrenme düzeyleri düzenleyici role sahiptir) doğrulanmamıştır.

\section{Sonuç ve Öneriler}

Yaşlı nüfusun ve yaş ayrımcılığının hızla artışı, gençlerin ileride yaşlılarla ilgili bir kurumda çalışma, yaşlıların sosyal çevrelerinde bulunma veya yaşlı yakınlarına bakım veren rolü üstelenme olasılıklarını artırmaktadır. Bu bağlamda gençlerin yaşlılara dair tutumlarının kaynağını araştırmak önem teşkil etmektedir. Yaşlı ayrımcılığ dair olumsuz tutumlar, aile ve diğer ortak yaşam alanlarındaki paylaşımları ve sağlık hizmetlerine erişim gibi konularda karşımıza çıkmaktadır. Araştırmalarla gençlerin yaşlılara dair algılarının belirlenmeye çalışılmasının bir amacı da yaşlı ayrımcılığının gençler üzerinden körükleniyor olmasıdır. Yaşlılığın ölüme yaklaşmakla ilişkilendirilmesi, medyada gençliğin güzelliğin pazarlanışı hatta öne çıkan önemli değerlerden biri olarak gösterilmesi, yaşlılığın savaşılması gereken bir konum olarak anlatılması kuşaklar arası çatışmaya ve kopukluğa sebebiyet verebilmektedir. Bu sebeple gençlerin yaşlılık dönemine dair algılarının ne olduğu ve sebeplerinin anlaşılması, yaşlılara dair yaklaşımlarının değişebilmesi açısından önem taşımaktadır.

Yaşlanmaya nasıl yaklaşılacağı ve buna nasıl uyum sağlandığı konusunda hangi faktörlerin rol oynadığını bilmek sorulması gereken sorular arasındadır. Böylelikle, gelecekte yaşlılıkla ilgili merkezlerin oluşumu şekillenebilir, yaşlılığa dair eğitim planlamalarıyla yaşlılara ilişkin görüşlerin nasıl farklılaşabileceğiyle ilgili adımlar atılabilir. Ne türdeki kişilik özelliklerinin yaşlılığa karşı pozitif bir bakış açısı 
kazandırdığını tespit etmek, işe alım zamanlarında yaşlıları ilgilendiren kurumlarda görev yapacak kişilerin karakter özelliklerini belirlemekte ve buna uygun ölçekler üretebilmekte önem taşır (Arslan, 2016). Bu çalışmada gençlerin kişilik özellikleri ile yaşlılara olan tutumları arasındaki ilişkide yaşam boyu öğrenme eğilimlerinin düzenleyici rolünü incelemek amaçlanmıştır. Ayrıca cinsiyet, yaş ve gencin yaşlı bir yakını ile beraber yaşayıp yaşamama değişkenlerine göre de gençlerin yaşlılara dair tutumlarında bir farklılaşma olup olmadığına bakılmıştır.

Çalışma bulgularının sonuçlarına göre gençlerin cinsiyeti ve yaşlı bir yakınları ile bir süre beraber yaşamış olma ya da olmama durumları, yaşlılara karşı tutumlarında bir ayrım yaratmamaktadır. Başka çalışmalarda da benzer sonuçlar bulunmaktadır. Büyük ebeveynlerle birlikte oturmanın yaşlılığa dair tutumları etkilemediği ortaya konmuştur (Özbek-Yazıcı vd., 2015; Salman vd., 2018). Aksini belirten bazı çalışmalar da bulunmaktadır. Lasher \& Faulkender (1993) in çalışmalarında, genç yetişkinlerden yaşlı yetişkinlerle temas sıklığı azalmış olanların, yaşla birlikte fiziksel görünümün nasıl değiştiğine dair önemli ölçüde daha fazla endişe bildirdikleri bulunmuştur. Yaşlı yetişkinlerle daha az temas halinde olanlar, fazla temas halinde olan gençlere kıyasla yaşlanmayla ilişkili kayıplara ve yaşlılığa dair daha fazla kaygı duyduklarını dile getirmişlerdir. Yaşlı ile zayıf temas kalitesi gençlerde yaşlılığa ilişkin daha yüksek kaygı ile ilişkilendirilmiştir. Yaşlı yetişkinlerle sık karşılaşmalar ve güçlü kişisel ilişkiler (özellikle büyük büyükanne ve büyükbabalar olmak üzere) yaşlı yetişkinlere karşı olumlu tutumlara katkıda bulunan en önemli faktörler arasındadır (Chu \& Chu, 2013). Yaşlı insanlarla sık s1k temas kuran öğrencilerin daha olumlu tutumlar sergiledikleri ve 65 yaş ve üstü insanlara karşı daha az önyargılı davrandıkları bulunmuştur (Bousfield \& Hutchinson, 2010). Bu bulguların yapılan çalışma ile tutarlı olmamasının, yaşlılarla sosyal aktiviteler yapmak ve zaman geçirmek ile evde uzun süre hasta bir yaşlının bakımını üstlenmek ya da buna şahit olmak arasındaki farklardan kaynaklandığı düşünülebilir. Ayrıca bu çalışmanın sonuçlarında, yaşlı bir yakın ile bir süreliğine beraber yaşamış olmak ya da olmamak arasında bir farkın olmayışının önemli nedenlerinden biri o yaşlı yakınların kişilik özelliklerinin, içinde bulunulan toplumun benimsediği kültürel ve geleneksel ideolojilere göre değişim göstermesidir.

Diğer demografik değişkenlerden biri olan cinsiyet de gençlerin yaşlılara dair tutumlarında herhangi bir farklılığa yol açmamıştır. Literatürde de bunu destekleyen sonuçlar bulunmaktadır (Kaçan vd., 2018). Bununla birlikte genellikle üniversite öğrencileri arasında yapılan bazı çalışmaların sonuçlarına göre kadın öğrencilerin erkek öğrencilere kıyasla yaşlılara daha olumlu tutumlar içinde oldukları tespit edilmiştir. Toplumsal roller bağlamında bakım vermek ve kapsayıcı olmak bakımından kadına yüklenen anlamlardan dolayı böylesi bir farklılaşma olduğu düşünülebilir (Dinçer vd., 2016).

Bir diğer demografik değişken olan yaş ile yaşlılara dair tutumlar arasında anlamlı bir ilişkiye rastlanılmamıştır. 17-29 yaş arası genç yetişkin ve beliren yetişkin olarak adlandırılır ve birbirine yakın gelişimsel dönemleri temsil eder. Elde edilen bulgunun örneklemin gelişim dönemlerinin benzer özellikler taşımasından kaynaklandığı düşünülebilir. $\mathrm{Bu}$ bağlamda, gelecekteki çalışmalarda yaş aralığ 1 daha geniş 
tutulduğunda yaşlılığa ilişkin tutumlar arasında farklılıklar gözlenebileceği düşünülmektedir.

Çalışma bulgularına göre gençlerin kişilik özellikleri ile yaşlılara dair tutumları arasında istatistiksel açıdan anlamlı ilişkiler bulunmuştur. Literatürde bu konu ile yapılan az sayıda çalışma sonuçları da bu çalışma sonuçları ile tutarlılık göstermektedir. Yapılan bir çalışmaya göre, kural bilincine sahip olan kişiler, sorumluluk sahibi, uyumlu, ahlaklı, vicdanlı ve sosyal açıdan uygun tutum gösterme eğilimindedirler. Bu özelliklere sahip kişilerin yaşlılara yönelik tutumlarının daha olumlu olduğu söylenmektedir (Burks, Youll \& Durtschi, 2012). Sicaklık (dişa dönük, kibar ve uysal), duygusal istikrar (olgun ve gerçekçi) ve düşük gerilimin (rahat, sakin ve sabırlı) de yaşlı yetişkinlere yönelik olumlu tutumlarla ilişkili olduğu bulunmuştur (Richardson, Lounsbury, Bhaskar, Gibson \& Drost, 2009). Bu kişiler sosyal etkileşimin gerekli olduğu ve yardıma dayalı mesleklerde özellikle geriatrik popülasyonlarla iyi çalışacaklar ve kurallara duyarlı bir tavırla sosyal olarak arzu edilen davranış kalıplarına bağlı kalacaklardır. Başka bir çalışmada yaşlı insanlara karşı olumlu tutumları olan bireylerin, duygusal ve estetik açıdan hassas, kendine ve başkalarına karșı hoşgörülü ve onlarla daha sıkı bağlar kurmaya eğilimli oldukları söylenmiştir. Yüksek duyarlı sezgisel özellikleri sebebiyle yaşlılıkta savunmasızlık ve bağımlılık hallerini daha fazla kabul edip, arkadaşlarına ve ailelerine daha fazla yardım davranışlarında bulunurlar. Yaşlılı̆̆ aktivitelerden kaçınılmaz bir gerileme ve geri çekilme zamanı olarak değil, düşünceye daha fazla kapılmak için bir firsat olarak görürler. Daha endişeli kişiler, tipik olarak daha savunmasız insanlarla özdeşleşir ve onlardan endişe duyma eğilimindedirler. İyi dengelenmiş, dirençli ve güvende hisseden düşük kaygılı kișiler, yaşlılara karşı daha olumlu tutumlara sahiptirler (Katz, 1990).

Sağlık çalışanları ile yapılan bir çalışma, hemşirelerin uyumluluk ve nevrotiklik özelliklerinin yaşlı insanlara yönelik tutumlarını anlamlı şekilde yordayabileceğini göstermiştir. Hemşirelerin uyumluluk ile yaşlılara yönelik tutumları arasında olumlu ve anlamlı bir ilişki gözlenmiştir. Ayrıca, insanlarla anlaşabilme kapasitesi yüksek bir kişinin daha fazla hayırsever ve kişilerarası iletişiminde empati, iş birliği ve destekleyici olduğu ifade edilir. Sonuçlar ayrıca nevrotikliğin hemşirelerin yaşlı insanlara karşı tutumları ile güçlü negatif ilişkisi olduğunu da göstermiştir (Yazdanian vd., 2016). Bu araştırma sonuçları, yapılan çalışma sonuçları ile tutarlıdır. Gençlerin uyumluluk kişilik özellikleri ve dışadönüklük kişilik özellikleri ile yaşlılara dair tutumları arasında pozitif bir ilişkiye rastlanırken, nevrotiklik kişilik özelliği ile yaşlılara karşı tutumlar arasında negatif yönlü bir ilişki bulunmuştur. Bu sonuç diğer bazı çalıșma sonuçları ile de tutarlıdır. Nasseh ve arkadaşlarının (2012) yaptığı bir çalışma, nevrotikliği yüksek olan bireylerin anksiyete, güvensizlik, öfke ve başkalarına karşı olumsuz tutum gibi belirtiler yaşadıklarını ve bunun da kişisel başarılarının azalmasına yol açtığını göstermiştir. Bazı kanıtlar, yüksek nevrotiklik puanlarına duygusal istikrar eksikliği, korku, üzüntü, kafa karışıklığı, öfke, suçluluk ve nefret gibi olumsuz duyguların eşlik ettiğini ve yüksek nevrotikliği olan kişilerin dürtüselliğe ve saldırganlığa daha yatkın olduklarını göstermiştir (Atari vd., 2006). Yüksek nevrotiklik, etkisiz başa çıkma becerileri ve yaşam memnuniyetsizliği ile ilişkilidir (Costa \& McCrae, 1986). Yapılan başka bir çalışmada 
da nevrotiklik, uyumluluk, dişadönüklük ve sorumluluk özellikleri yaşlanma kaygısı puanlarıyla ilişkili bulunmuştur. Beklendiği gibi, nevrotiklik yaşlanma ile ilgili kaygılarla, diğer kişilik özelliklerine kıyasla en güçlü ilişkiyi kuran kişilik özelliği olarak tespit edilmiştir (Harris \& Dollinger, 2003). Bu sonuçlar nevrotiklik düzeyi yüksek gençlerin, yaşlılarla ilgili ortak aktivitelere katılmak, onlara bakım sağlayıcılıkla ilgili destekte bulunmak, yaşlılarla etkileşim içinde olmak veya yaşlıların olduğu iş kollarının içinde yer almak gibi durumlarda olumsuz tutumlar gösterebileceklerine dair fikir sağlayabilir.

Aynı çalışmanın diğer bulguları da bu çalışma sonuçları ile tutarlıdır. Sorumluluk ve deneyime açıklık değişkenleri hemşirelerin yaşlılara yönelik tutumu ile ilişkilendirilmemiş, benzer şekilde bu çalışmada da deneyime açıklık ve sorumluluk özellikleri, gençlerin yaşlılara ilişkin tutumlarını yordamamıştır (Yazdanian vd., 2016). Nasseh ve arkadaşları (2012) dışa dönüklük ve duygusal tükenmişlik arasında anlamlı negatif bir ilişki olduğunu bildirmişlerdir. Dışa dönük insanların olumlu duyguları, onları gelecekteki mesleki işlevleri konusunda umutlandırabileceğinden, duygusal tükenmişlik düzeylerinin daha düşük olması ve dolayısıyla yaşlı insanlara karşı daha uygun işlev ve tutuma sahip olmalarına yol açabilmektedir.

Nevrotiklik hali, yani kişilerin duygusal dengesizlik halleri azaldıkça yaşam boyu öğrenme düzeyinin arttığ görülmektedir. Bu durum kişilerin yaşamlarında belirli bir dengeye tekrar kavuştuklarında kendilerini geliştirmek ve yeniliklere açık olabilmek için daha fazla istek ve arzuya sahip olabileceği şeklinde açıklanabilir (Tarhan vd., 2017). Yapılan bir çalışmada bireysel yenilikçilik kişilik özelliğinin yaşam boyu öğrenme becerisinin alt boyutlarından "deneyime açıklık" "motivasyon" ve "sebat" özellikleri ile doğru orantılı anlamlı bir ilişki ortaya konmuştur. (Mülhim, 2018). Çalışmada beden eğitimi spor yüksek okulu öğrencilerinin yenilikçilik kişilik özelliklerinin, yaşam boyu öğrenme eğilimlerini etkilediği sonucuna varılmıştır (Mülhim, 2018). Buradan yola çıkarak bu çalışmada da ele alınan 5 faktör kişilik özellikleri ile yaşam boyu öğrenmenin, yaşlılara karşı tutumları nasıl etkileyebileceği araştırılmıştır. Çalışmada merak edilen diğer temel soru da gençlerin kişilik özellikleri ile yaşlılara dair tutumları arasındaki ilişkide yaşam boyu öğrenme eğilimlerinin düzenleyici bir rolünün olup olmadığı şeklindedir.

Gençlerin uyumluluk özellikleri ile yaşlılara yönelik tutumları arasındaki doğru orantılı ilişkide yaşam boyu öğrenme düzeyi düzenleyici rol oynar. Gençlerin dışadönüklük özellikleri ile yaşlılara yönelik tutum arasındaki bu doğru orantılı ilişkide yaşam boyu öğrenme düzeyinin düzenleyici etkisi vardır. Gençlerin nevrotiklik kişilik özelliği ile yaşlılara yönelik tutumları arasında ters orantılı ilişkide yaşam boyu öğrenme eğilimlerinin düzenleyici rolü bulunmaktadır. Uyumluluk, dışadönüklük ve nevrotiklik kişilik özellikleri ile yaşlılara karşı olumlu tutumlar arasındaki ilişkide ancak yaşam boyu gelişim düşük ve orta düzeyli iken bu ilişkilerin gücünü arttırmaktadır. Fakat yaşam boyu öğrenme düzeyi yüksek olduğunda yaşlilara dair olumlu tutum üzerindeki etkisi anlamsızlaşmaktadır. Yaşam boyu öğrenme kavramı kişilerin yaşamlarını yönetebilmeleri adına ihtiyaç duydukları bilgileri edinebilme becerisi olarak tanımlanmaktadır. $\mathrm{Bu}$ tanım itibari ile ögrenme etkinliklerinin her şeye mahsus bir 
ihtiyaç olabileceği fikrini benimseyen gençlerin bu bakış açıları, yaşlılara dair olumlu tutumlarına da yansımaktadır. Fakat bu durum yaşam boyu öğrenme ihtiyacının düşük ve orta düzeyde olduğu zamanlar için geçerlidir. Yaşam boyu öğrenme düzenin yüksel olduğu durumlarda ise, her yaşta öğrenebilme fikrinin içselleşmesinden ziyade, gençlerin kendi öğrenme etkinlikleri ile daha çok ilgilenmeleri, kendi gelecek planlamaları üzerine kafa yorma hallerinin artması ve kendilerine dönük eylemlerinin fazlalaşması düşünülebilir. Gençlerin yaşam boyu öğrenme düzeyi yükseldikçe bu eğilimin yaşlılık ve yaşlılara dair tutumları üzerinde etkilerindense, kendilerini daha ön plana koydukları bireysel yaşam planlarının ve içinde bulundukları öğrenme etkinliklerini organize etmek üzerine olan etkilerinin arttığı düşünülebilir.

Alan yazında yaşam boyu öğrenme ve kişiliğin yaşlılara dair tutumda bütünleşik etkisini gösteren bir çalışmaya rastlanılmamıştır. Yaşam boyu öğrenme ile ilgili de daha çok yapılan çalışmalar, yaşlıların aktif ve başarılı yaşlanması için yaşam boyu öğrenmenin değerinin altını çizen niteliktedir (Mackowicz \& Wnek-Gozdek, 2016). Yapılan bu çalışma gençlerin yaşlılara dair tutumlarında olumlu bir bakış açısı kazanmaları için ne türde çalışmalar yapılabileceğine kılavuzluk edebilmesi açısından işlevseldir. Gençlerin yaşam boyu öğrenme fikrini içselleştirebilmeleri başka bir deyişle her yaşta bireylerin yeni bilgi sistem ve teknolojilere uyum sağlayabileceğine ve öğrenme etkinlikleri ile uğraşabileceğine dair inanç geliştirmeleri, hem kendi yaşlılık tasarımlarına dair olumlu bir beklenti oluşturabilir hem de toplumdaki yaşlı kesimin daha az yargı ve ayrımcılıkla karşı karşıya gelmesini sağlayabilir.

Gençlerin ve yetişkinlerin yaşlılara dair algılarının değişmesi, artan yaşlı nüfusu ve ülkenin koruyucu sosyal politikalarının yetersizliği sebebiyle oldukça önemlidir. 1946 ve 1964 yılları arasında doğmuş olan bebek patlaması kuşağına mensup yaşlılar, özellikle genç nesillerin tutumları konusunda endişelidirler. Gençlerin yaşlılara dair algıları yaşlı kimselerin yaşam memnuniyeti üzerinde etkili olmaktadır (Kurtkapan, 2020).

Bazı araştırmacılar, gençlerin yaşlılara dair tutumları ile yaşlı kimsenin bilişsel işlevi, sağlık durumu, öz bakım düzeyi (ör. hijyen), kişilik faktörleri (örneğin huysuz) ve yaşlı yetişkin bireylerle bir süre bir arada olma eksikliği gibi faktörlerin ilişkili olduğunu savunmuşlardır. 65 yaş üstü grupta hızla artan insan sayısına rağmen, yaşlı bireyler hala marjinalize edilmiş, zayıf, çaresiz ve potansiyel bakım veren yakınları için bir yük olarak tasvir edilmektedir. (Mansfiel-Green vd., 2015).

Yaş ayrımcılığının ve yaşlı insanlara yönelik olumsuz tutumların kaynaklarını anlamak, gerontologların, ruh sağlığı çalışanlarının ve sivil toplum kuruluşlarının, gerontolojik eğitime gerontofobi ve toplumdaki kişilerin genel olarak yaşamdaki anlam kaybı ve nihayetinde ölümle ilgili korkularıyla yüzleşmek gibi yeni ve ek odak sağlamalarını gerektirebilir (Katz, 1990). Gençlerin yaşlılarla ilişkili algılarını tespit etmek ve değişmesi için çabalamak toplumsal eşitliğin yolunu açması ve yaygınlaşmasına katkı sağlaması açısından önemlidir. Tutumlarla ve davranışlarla ilişkili olarak tanımlanan kişiliği anlamanın yollarını bulmak ve bunları yaşlı yetişkinlerle ilgili eğitim programlarına entegre etmek, genel halkı da olumlu tutumlara teşvik edebilir (Cornwell, 2012). Kişilik özelliklerinden uyumlu, dişadönük ve duygusal dengesi çok 
daha tutarlı ve yaşam boyu öğrenme eğilimleri fazla olan kişilerin, yaşlılarla ilgili mesleklerde istihdam edilmesinin daha işlevsel olacağ düşünülmektedir. Yaşam boyu öğrenme eğilimleri yüksek kişiler yatkın oldukları mizaçlarına ek olarak yaşam devam ettiği sürece öğrenmenin ve gelişmenin mümkün olduğuna inandıkları için yaşlıları atıl ve işe yaramaz olarak görmeyeceklerdir. Bu fikir de yaşlilara yönelik tutumlarının olumlu yönde gelişmesini ve sürmesini sağlayacaktır. Yapılan bir çalışmada iş yerinde performans değerlendiricilerin yaşlılara dair olumsuz algılarının, gençlere benzer tavırlar içinde olan, öğrenme gerektiren konularda gençler gibi aktiflik gösteren yaşlılara karşı oldukça azaldığını ortaya koymuştur (Kite vd., 2005).

Yaşam boyu öğrenme fikrinin gençler tarafindan içselleştirilebilmesi için akademisyenlere yönelik de yenilikçi, yaratıcı, yaşam boyu öğrenme gibi konularda mesleki ve kişisel gelişim programları düzenlenebilir (Mülhim, 2018). Üniversite müfredatlarında da özellikle de eğitim fakültelerinde yaşam boyu öğrenmeyi destekleyici çalışmaların planlaması yapılmalıdır (Tarhan vd., 2017). Yapılan bir çalışma üniversite öğrencilerinin yaşlılara dair tutumlarının bazı ders müfredatlarına yapılabilecek müdahalelerle sorgulanabileceği ve değişebileceğini söylemektedir (Wurtele \& Maruyama, 2013). Ömür boyu sürebilecek bir insani gelişim kursu tasarlanan bir çalışmada kursun bir kısmını da "yaşlı yetişkinlerin faaliyetleri" oluşturmaktadır. Bu kursta denek olarak yaşlılarla vakit geçirerek çalışmayı kabul eden öğrencilerin yaşlılara yönelik tutumlarında olumlu değişiklikler kaydedilmiştir (Wurtele \& Maruyama, 2013). Yapılan başka bir çalışmada yaşlılığa dair daha olumlu bir bakış açısına sahip olanların çalışma yaşamında daha fazla yaşlı kişilerle iş arkadaşı olma arzusu içinde oldukları tespit edilmiştir (Kurtkapan, 2020). Hemşirelik, tıp, fizyoterapi, sosyal hizmet ve ruh sağlığı alanları, yaşı bakımı bölümlerinde okuyan öğrencilerin müfredatlarının yeniden yapılandırılması, artan yaşlı nüfusun varlığında toplumun tüm üyelerinin yaşlı yetişkinler hakkında doğru bilgi ve olumlu tutuma sahip olabilmeleri için acil bir ihtiyaçtır.

Çalışmada bazı sınırlılıklar da mevcuttur. Araştırma kapsamına alınan gençlerin farklı alt kültürleri de temsil edebilmeleri ve böylece yaşlılığa dair bakış açılarının da farklılaştığını görmek açısından Türkiye genelinde bir tarama yapılabilirdi. Katılımcıların bakımevi veya huzurevi gibi kurumlarda yaşayan yaşlı akrabalarının olup olmadığı da demografik sorulara dahil edilebilirdi. Yaşam boyu öğrenme kavramı bu çalışmada yüksek olduğu durumlarda yaşlılara dair olumlu tutum üzerinde kişilik özellikleri ile kurulan ilişkide anlamlı bir düzenleyici olamamıştır. Gençler ölçek sorularına yanıt verirken kendi ögrenme etkinliklerini planlayabilmek adına düşünmüş bunu kendi yaşlılık dönemleri ya da etrafta bulunan yaşam boyu öğrenen yaşlıların varlığı ile beraber düşünmemiş olabilirler. Başka çalışmalarda yaşam boyu öğrenme düzeyi yüksek olan yaşlılarla ilgili fikirlerini ele alan bir ölçek ya da açık uçlu sorular dahil edilip, bu fikrin yaşlılara dair tutumlarına nasıl yansıdığı daha açık bir şekilde tartışılabilir.

Türkçe literatürde yaşlılıkla ilgili yapılan çalışma sayısı oldukça azdır. Bu alanda tez projelerinin ve bilimsel yayın sayılarının fazlalaştırılması önerilebilir. Böylelikle yaşam boyu öğrenme aktif yaşlanma amaçlarının belirlenmesi de sağlanabilir. Ayrıca Y, Z gibi 
genç kuşaklar arasında yaşlılara dair tutum farklılıklarının kıyasları yapılabilir ve başka ne türde kişilik özelliklerinin tutumlara etkisi olabileceği araştırılabilir. Örneğin empatik olmak gibi sonradan da öğrenilen ve içselleştirilebilen birtakım özelliklerin yaşlılara dair olumlu tutumlarla olan ilişkilerinin incelenmesi, öğrenme yolu ile gençlerin tutumlarının iyileşmesine katkı sağlayabilir. 21. Yüzyılın ikinci yarısına dönük zamanlarda yaşlı bakımına olan ihtiyaç göz önüne alındığında bu bakımdan sadece ailenin ya da sosyal devletin sorumlu tutulmaması, tüm toplum üyelerinin ve özellikle gençlerin bakış açılarının da sorumlu tutulması ve değer yargılarının yeniden belirlenip üretilmesi gerekmektedir. $\mathrm{Bu}$ sebeple yaşlanmanın gücü, yaşlanırken kazandıklarımız ve kaybettiklerimiz, yaşlılık sürecinde hem devlet hem aile, ancak bir yandan da diğer yaş dönemlerinde olanların desteğinin birleşiminin önemi çeşitli seminerler ve eğitim programları ile yaygınlaştırılmalıdır.

\section{Kaynaklar}

Adibelli, D. (2011). The validity and reliability of Kogan's attitude towards old people scale in the Turkish society. Health, 3(09), 602.

Akdemir, N., Çınar, F. \& Görgülü, Ü. (2007). Yaşlılığın algılanması ve yaşlı ayrımcılığı. Turkish Journal of Geriatrics, 10(4), 215-22.

Atari, U., Amanalahi, A. ve Mehrabizade, M. (2006). Investigate the relationship between personality and individual factors - family and marital satisfaction in governmental offices in Ahwaz. Journal of Education and Psychology, 13, 81-108.

Aydın, A. \& Sayılan, A. A. (2014). Aktif yaşlanma ile yaşam boyu öğrenme arasındaki ilişkiye teorik bir bakış. International Journal of Social and Economic Sciences, 4(2), 76-81.

Baltes, P. \& Labouvie, G. (1973). Adult development of intellectual performance: Description, explanation, modification. In C. Eisdorfer ve M. P. Lawton (Çev.), The psychology of adult development and aging. American Psychological Association,

Barrett, L. F. \& Pietromonaco, P. R. (1997). Accuracy of the five-factor model in predicting perceptions of daily social interactions. Personality ve Social Psychology Bulletin, 23(11), 1173-1188.

Barry, B. \& Stewart, G.L. (1997). Composition, process and performance in selfmanaged groups: The role of personality. Journal of Applied Psychology, 82 (1), 62 78.

Bousfield, C., \& Hutchison, P. (2010). Contact, anxiety, and young people's attitudes and behavioral intentions towards the elderly. Educational Gerontology, 36, 451466. http://doi.org/cm7prq

Burks, D. J., Youll, L. K. \& Durtschi, J. P. (2012). The empathy-altruism association and its relevance to health care professions. Social Behavior and Personality: An international journal, 40, 395-400. 
Gençlerin Kişilik Özellikleri ile Yaşlılara Karşı Tutumları Arasında

Yaşam Boyu Öğrenmenin Düzenleyici Rolünün İncelenmesi

Canatan, Ü. \& Boz, H. (2019). Hayat boyu öğrenme etkinliklerine katılımın aktif yaşlanmanın desteklenmesindeki rolü. Social Sciences, 14(3), 343-363.

Cattell, R. B., Eber, H.W. \& Tatsuoka, M.M. (1970). Handbook for the Sixteen Personality Factor Questionnaire (16PF). Institute for Personality and Ability Testing.

Chu, A. Z. \& Chu, R. J. (2013). Service willingness and senior tourists: Knowledge about aging, attitudes toward the elderly, and work values. The Service Industries Journal, $33,1148-1164$.

Cornwell, J. (2012). The care of frail older people with complex needs: Time for a revolution. UK: King's Fund.

Costa, P. T. Jr. \& McCrae, R. R. (1986). Cross-sectional studies of personality in a national sample: I. Development and validation of survey measures. Psychology and Aging, 1, 140-143.

Coşkun, Y. D. \& Demirel, M., (2009). Üniversite öğrencilerinin meraklılık düzeylerinin bazı değişkenler açısından incelenmesi. Mehmet Akif Ersoy Üniversitesi Ĕgitim Fakültesi Dergisi, 18, 111-134.

Diker Coşkun, Y. \& Demirel, M. (2012). Üniversite öğrencilerinin yaşam boyu öğrenme eğilimleri. Hacettepe Üniversitesi Eğitim Fakültesi Dergisi, 42, 108-120.

Dinçer, Y., Usta, E. \& Bulduk, S. (2016). Üniversite öğrencileri gözüyle yaşl1lık nasıl algılanıyor? Yaşlı Sorunları Araştırma Dergisi, 9(1), 26-38.

Dollinger, S. J., Leong, F. T. L. \& Ulicni, S. K. (1996). On traits and values: With special reference to openness to experience. Journal of Research in Personality, 30, 23-41.

Duyan, V. \& Gelbal, S. (2013). Yaşlılara yönelik tutum ölçeği'nin bir grup üniversite öğrencisi üzerinde Türkçe'ye uyarlama çalışması. Turkish Journal of Geriatrics/Türk Geriatri Dergisi, 16(2).

Edwards, A. (1959). Edwards Personal Preference Schedule, Revised Manual. The Psychological Corporation.

Epçaçan, C. (2013). Yaşam boyu öğrenme becerilerinin ders kitaplarında yer alma düzeyine örnek bir inceleme. Adlyaman Üniversitesi Sosyal Bilimler Enstitüsü Dergisi Türkçenin Ĕ̈itimi Öğretimi Özel Sayısl, 7(11), 353-379.

Erdemir, F. (2017). Yaşlanma ve yaşlıllğa ilişskin inanç ve tutumlar. Vize Yayıncılık.

Günüç, S., Odabaşı, H. \& Kuzu, A. (2012). Yaşam boyu öğrenmeyi etkileyen faktörler. Gaziantep Üniversitesi Sosyal Bilimler Dergisi, 11(2), 309-325.

Hamadani-Zadeh, F., Motahediyan Tabrizi, E., Sarhangi, F. \& Zigheymat F. (2008). Survey the nurses' attitudes toward health care of elderly patients. Kowsar Med Journal, 13, 253-8. 
Harris, L. A. \& Dollinger, S. M. C. (2003). Individual differences in personality traits and anxiety about aging. Personality and Individual differences, 34(2), 187-194.

John, O. P. \& Srivastava, S. (1999). The Big Five trait taxonomy: History, measurement, and theoretical perspectives. In L. A. Pervin, ve O. P. John (Çev.). Handbook of personality: Theory and research. Guilford Press.

John, O.P, Donahue, E. M. \& Kentle, R. L. (1991). The big five inventory-versions $4 a$ and 54. Berkeley, CA: University of California, Institute of Personality and Social Research.

Kaçan, H., Dibekli, E. \& Akkan, K. (2018). Toplumda yaşayan bireylerin yaşlı ayrımcıllı̆̆ tutum düzeylerinin incelenmesi. Yaşlı Sorunları Araştırma Dergisi, 2, 815.

Katz, R. S. (1990). Personality trait correlates of attitudes toward older people. The International Journal of Aging and Human Development, 31(2), 147-159.

Kite, M. E., Stockdale, G. D., Whitley Jr, B. E. \& Johnson, B. T. (2005). Attitudes toward younger and older adults: An updated meta-analytic review. Journal of Social Issues, 61(2), 241-266.

Kogan, N. (1961). Attitudes toward old people: the development of a scale and an examination of corraletes. Journal of Social Psychology, 64, 44-54.

Kurtkapan, H. (2020). Y kuşağı gençliğinin yaşlılık ve yaşlanmaya ilişkin tutumları: Nevşehir örneği. Yaşlı Sorunları Araştırma Dergisi, 13(1), 48-55.

Lasher, K. \& Faulkender, P. J. (1993). Measurement of aging anxiety: development of the Anxiety about Aging Scale. International Journal of Aging and Human Development, 37, 247-259.

Lutsky, N. (1980). Attitudes Toward Old Age and Elderly Persons, in Annual Review of Gerontology and Geriatrics, Springer.

Mansfield-Green, S., Morrisseau, N. R., Valliant, P. M. \& Caswell, J. M. (2015). Undergraduate students' attitudes toward, and personality correlates in relation to, older adults. Social Behavior and Personality: An International Journal, 43(10), 1741-1748.

March, G. B., Hooper, J. O. \& Baum, J. (1977). Life span education and the older adult: Living is learning. Educational Gerontology, 2(2), 163-172.

Mackowicz, J. \& Wnek-Gozdek, J. (2016). "It's never too late to learn"- How does the Polish USA change the quality of life for seniors? Educational Gerontology, 42(3), 186-197.

McCrae, R. R. V\& Costa, P. T. (1987). Validation of the five-factor model of personality across instruments and observers. Journal of Personality and Social Psychology, 52(1), 81-90. 
Gençlerin Kişilik Özellikleri ile Yaşlılara Karşı Tutumları Arasında

Yaşam Boyu Öğrenmenin Düzenleyici Rolünün Íncelenmesi

McTavish, D. (1971). Perceptions of old people: A review of research methodologies and findings. Gerontologist, 11, 90-101.

Mischel, W., Shoda,Y. \& Ayduk, Ö. (2008). Introduction to personality. John Wiley ve Sons.

Moody, H. R. (1976). Philosophical presuppositions of education for old age. Educational gerontology, 1(1), 1-16.

Mülhim, M. A. (2018). Beden eğitimi ve spor yüksekokulu öğrencilerinin bireysel yenilikçilik düzeyleri ve yaşam boyu ögrenme ĕgilimlerinin incelenmesi: Bartın Üniversitesi örneği. Yüksek Lisans Tezi. Bartın Üniversitesi, Eğitim Bilimleri Enstitüsü.

Nasseh, M., Jalilvand, J. \& Vahdani, M. (2012). Relationship between personality dimensions and job burnout of Nurses. Modern Care, 9, 87-94.

Oktay, S. (2019). Akıcı Zekanın Kişilik Özelliklerini Yordama Gücü. Yüksek Lisans Tezi. Aydın Adnan Menderes Üniversitesi, Sağlık Bilimleri Enstitüsü.

Özbek-Yazıcı, S., Kalaycı, I., Kaya, E. \& Tekin, A. (2015). Yaşlı bakım programı öğrencilerinin yaşlı ayrımcılığına ilişkin tutumları. Yaşlı Sorunlarını Araştırma Dergisi, 2, 77-87.

Panaghi, L., Pirouzi, D., Shirinbayan, M. \& Ahmadabadi, Z. (2011). The role of personality and demographictraits in spouse abuse. Iranian Journal of Psychiatry and Clinical Psychology, 17(2), 126-135.

Richardson, J. D., Lounsbury, J. W., Bhaskar, T., Gibson, L. W. \& Drost, A. W. (2009). Personality traits and career satisfaction of health care professionals. The Health Care Manager, 28, 218-226.

Salman, M., Gülçek, E., Aylaz, R. \& Polat, F. (2018). Hemşirelik öğrencilerinin yaşlılara karşı tutumlarının değerlendirilmesi. Yaşlı Sorunları Araştırma Dergisi, 11 (2), 1-7.

Schmitt, D. P., Allik, J., McCrae, R. R. \& Benet-Martinez, V. (2007). The geographic distribution of big fi ve personality traits: Patterns and profi les of human selfdescription across 56 nations. Journal of Cross-Cultural Psychology, 38(2), 173 212.

Sneed, C. D., McCrae, R. R. \& Funder, D.C. (1998). Lay conceptions of the five-factor model and its indicators. Personality and Socail Psychology Bulletin, 24, 115-126.

Sterns, H. L. \& Harrington, A. K. (2019). Lifespan Perspectives on Learning and Training. In Work Across the Lifespan. Academic Press.

Sung, K.T., Kim, B. J. \& Torres-Gil, F. (2010). Respectfully treating the elderly: Affective and behavioral ways of American young adults. Educational Gerontology, $36,127-147$. 
Sümer, N. \& Sümer, H. C. (2005). Beş faktör kişilik özellikleri ölçeği. (Yayınlanmamış çalışma).

Tarhan, S., Ekşioğlu, S. ve Gündüz, H. Ç. (2017). Yaşam Boyu Öğrenme Eğilimleri İle Özyetkinlik Beklentisi ve Kişilik Özellikleri Arasındaki İlişkinin İncelenmesi. Kastamonu Ĕ̈itim Dergisi, 25(5), 1925-1940.

Thorson, J.A. \& Perkins, M.L. (1981). An Examination of Personality and Demographic Factors on Attitudes Toward Old People. International Journal of Aging and Human Development, 12(2), 139-148.

Triandis, H. C. \& Bhawuk, D.P.S. (1997). Culture theory and the meaning of relatedness. San Francisco, CA: The New Lexington Press.

Turner, J. C. \& Oakes, P. J. (1989). Self-categorization theory and social influence. In P. B. Paulus (Ed.), The psychology of group influence (233-275). NJ: Erlbaum.

WHO. Active Ageing: A Policy Framework. http://whqlibdoc.who.int/hq/2002/WHO_NMH_NPH_02.8. pdf (Son Erişim Tarihi: 10.05.2014)

Wurtele, S. K., \& Maruyama, L. (2013). Changing students' stereotypes of older adults. Teaching of Psychology, 40(1), 59-61.

Yazdanian, A., Alavi, M., Irajpour, A. \& Keshvari, M. (2016). Association between nurses' personality characteristics and their attitude toward the older adults. Iranian Journal of Nursing And Midwifery Research, 21(1), 9. 